\title{
The cobweb theorem : a rational interpretation
}

Citation for published version (APA):

Borghans, L. (1991). The cobweb theorem : a rational interpretation. Researchcentrum voor Onderwijs en Arbeidsmarkt, Faculteit der Economische Wetenschappen. ROA Research Memoranda No. 7E https://doi.org/10.26481/umaror.199107E

Document status and date:

Published: 01/01/1991

DOI:

10.26481/umaror.199107E

Document Version:

Publisher's PDF, also known as Version of record

\section{Please check the document version of this publication:}

- A submitted manuscript is the version of the article upon submission and before peer-review. There can be important differences between the submitted version and the official published version of record.

People interested in the research are advised to contact the author for the final version of the publication, or visit the DOI to the publisher's website.

- The final author version and the galley proof are versions of the publication after peer review.

- The final published version features the final layout of the paper including the volume, issue and page numbers.

Link to publication

\footnotetext{
General rights rights.

- You may freely distribute the URL identifying the publication in the public portal. please follow below link for the End User Agreement:

www.umlib.nl/taverne-license

Take down policy

If you believe that this document breaches copyright please contact us at:

repository@maastrichtuniversity.nl

providing details and we will investigate your claim.
}

Copyright and moral rights for the publications made accessible in the public portal are retained by the authors and/or other copyright owners and it is a condition of accessing publications that users recognise and abide by the legal requirements associated with these

- Users may download and print one copy of any publication from the public portal for the purpose of private study or research.

- You may not further distribute the material or use it for any profit-making activity or commercial gain

If the publication is distributed under the terms of Article $25 \mathrm{fa}$ of the Dutch Copyright Act, indicated by the "Taverne" license above, 
THE COBWEB THEOREM: A RATIONAL INTERPRETATION

ROA-RM-1991/7E

Lex Borghans

RESEARCH CENTRE FOR EDUCATION AND LABOUR MARKET

Faculty of Economic Sciences

Rijksuniversiteit Limburg

Maastricht, September 1991 
CONTENTS

Page

ABSTRACT

i

1. INTRODUCTION

2. THE EQUILIBRIUM CONCEPT OF PRICES

3. IMPLICATIONS

4. CONCLUSIONS

REFERENCES 


\begin{abstract}
In contrast to the rational expectations theory, the cobweb theory is nowadays regarded upon as a theory in which people are 'myopic' and do not use information optimally. The original literature concerning the cobweb theory does, however, not suggest such a simple interpretation. In this paper an alternative interpretation of the cobweb theory is suggested in which the bias of expectations towards current prices is explained as an optimal trade off between the systematic error of 'myopic' expectations and the unavoidable errors in real forecasts.
\end{abstract}




\section{INTRODUCTION}

In 1930 Ricci, Tinbergen and Schultz published studies containing the first explicit models of a theory, which has since come to be known as the 'cobweb theorem'. This name stems from Kaldor (1934). The cobweb-theory has been the first explicit economic theory about expectations-formation. Later the construction of variants of this cobweb-theory, like extrapolative and adaptive expectations (see Shaw, 1989), leaded to the formulation of the rational expectations theory of Muth (1961). In the development of a new theory the interpretation of the predecessor very often gets adjusted to the new ideas. This also happened to the cobweb-theory, which is now typified as a naive theory of myopic agents, or as a special case of the rational expectation theory in which the stochastic process which generates future developments is, conditional on the information the agents have, a random walk.

Figure I: An illustration of the cobweb theorem by Schultz (1930), p. 34: 'Fixed demand curve and fixed supply curve with the time series that might be caused by them."

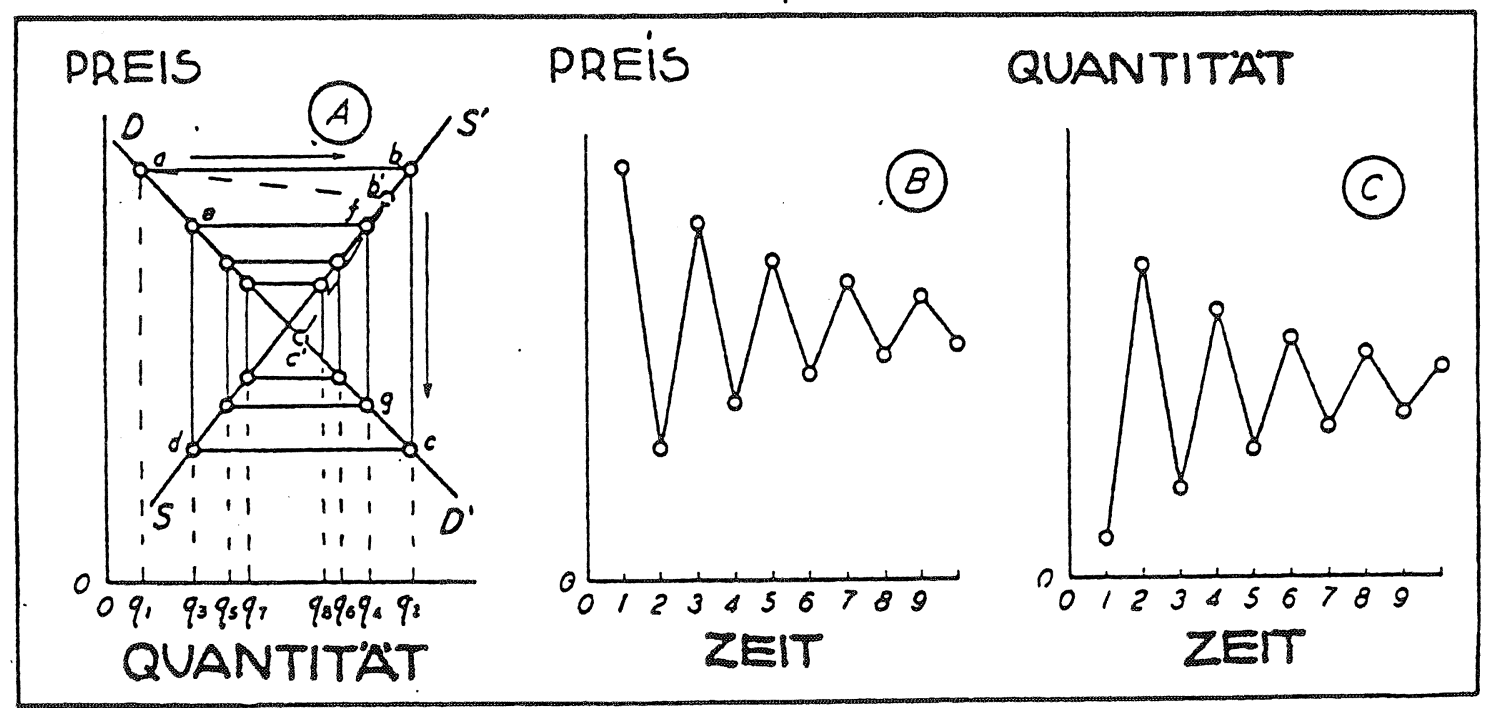

In my opinion this vision about the cobweb-theory is influenced by some economic concepts which are standard nowadays, but which did not exist in the thirties. Firstly, the present economic theory is dominated by the idea from Haavelmo (1944) that the economic development has to be viewed upon as a stochastic process. Secondly, the concept of equilibrium has changed throughout the years. Hicks (1933) defined equilibrium as 'the price which under constant conditions for demand and stock, can be preserved unlimited, in such a way that

1. 'Feste Nachfragekurve und feste Nachfragekurve [Most likely this should be 'Angebotskurve'] mit Zeitreihen, die sie verursachen können.' 
nobody is made to sell at a price different from the one that can be gained today'. ${ }^{2}$ Equilibrium of prices was equivalent to constant prices. Nowadays this constancy of prices has disappeared since 'a commodity is [...] defined by a specification of all its physical characteristics, of its availability date, and of its availability location. As soon as one of these factors changes, a different commodity results' (Debreu, 1956, p. 30).

This change of basic economic concepts makes it unfruitful to read the original cobwebliterature from a rational expectations point of view. Ignoring this change in point of view Keuzenkamp (1989) even discovers that Tinbergen (1932) 'explicitly uses rational expectations, but it disappeared under the dust of history' (p. 4).

The aim of this paper is to formulate a model which gives a different modern interpretation of the cobweb theory, which does better justice to the thoughts about expectation formation which underlie the cobweb theory. In this interpretation cobweb theory is the result of the dilemma between the Walrasian equilibrium theory of price taking agents and the idea that economic agents will be 'reasonable' (Tinbergen, 1933, p. 248). All formula's used in the paper are part of the interpretation. Only quotations stem directly from the original literature.

2. Hicks (1933), p. 442. '[Nun stellt man die Frage, welche] Preise bei gleichbleibenden Bedingungen für Bedarf und Vorrat auf unbegrenzte Zeit aufrechterhalten werden können, so daß niemand morgen zu anderen Preisen zu verkaufen veranlaßt ist als zu denen, die heute erzielt werden können'. 


\section{THE EQUILIBRIUM CONCEPT OF PRICES}

Cobweb theory is originated in the attempts of 'statisticians' to explain the real existing prices within the frameworks of Marshall or Walras and Pareto. Examples are studies of Moore (1929), Hanau (1927) and Haas and Ezekiel (1926). The problem these investigations were posed to was that the theory of general equilibrium ('the enchanting palace, which brings the imagination into ecstasy, but does not solve the question of the house ${ }^{3}$ ) is a static theory, unable to explain the easy perceptible fact that real world prices change from day to day.

In the static Walrasian model, equilibrium prices reflect the total availability and utility of goods in a society, indicating their 'subjective' value. It is therefore enough for people to be price taker, i.e. to compare their own subjective utility with the prices. Kaldor (1934, p. 123) illustrates this view by defining 'perfect knowledge' as 'all the relevant prices quoted in all markets are known to all individuals' (italics added). In a dynamic context, however, this leads to the paradox of the general equilibrium model. 'It so happens that the general equilibrium comes about, on the one hand by consumers and companies, maximising their utility, profit respectively, while on the other hand supply and demand for every good equal. The latter condition determines the prices. Prices are, however, for consumers and companies constant parameters. $^{4}$

Without giving a rationale like done by Hayek (1945) the cobweb-economists treat prices not just as economic parameters, but as indicators of the value of the subject. 'The 5,000,000 hog producers of this country use hog prices as an indication of when to increase their production and when to decrease, just as producers of all other commodities sold on a competitive market use prices as a guide to their operations'(Haas and Ezekiel, 1926). This value-revealing treatment of prices justifies the use of the current price as a proxy for the future (equilibrium) price:

(1) $p_{t}^{e q}=p_{t+d}^{e q}+\epsilon_{1} \quad$ with $\quad \sigma_{1}^{2}:=E\left\{\varepsilon_{1}^{2}\right\}$

3. Ricci (1930), 649. 'einem zauberhaften Palaste, der die Phantasie entzückt, aber das Problem der Wohnung nicht löst'.

4. Lange (1935), p. 359. 'Das allgemeine wirtschaftliche Gleichgewicht kommt nämlich dadurch zustande, daß einerseits die Konsumenten und die Unternehmer ihren Nutzen, bzw. ihren Profit maximaliseren, während andererseits das Angebot und die Nachfrage für jedes Gut gleich sind. Durch die letztere Bedingung werden die Preise bestimmt. Die Preise sind aber für die Konsumenten und für die Unternehmer konstante Parameter.' 
These 'natural' expectations, however, bring the equilibrium model into troubles. '[This assumption] we may thus regard as the "accepted framework" of static theory: and it is the sufficiency of this framework which is, in fact, contested when the "determinateness" of equilibrium is called into question' (Kaldor, 1934, p. 123-4). There are two problems related to the use of current prices as expectations for future prices. Firstly, this expectations scheme may lead to cobweb-cycles, and therefore the current prices partially lose their value-revealing meaning (For certain values of the parameters the cycle might even diverge). In that case current price is only a proxy for the equilibrium price, i.e. the value:

(2) $p_{t}=p_{t}^{e q}+\epsilon_{\Delta} \quad$ with $\sigma_{\Delta}^{2}:=E\left\{\epsilon_{\Delta}^{2}\right\}$

Secondly, there might be changes occurring which influence the future value of the object $\left(\epsilon_{1}\right.$ in equation (1)).

People can therefore improve their anticipations by trying to predict (i) to what extent current prices represent the equilibrium price, i.e. the value, and (ii) to what extent the future price will differ from the current value. Morgenstern (1935) thinks that '[b]esides the assumption of perfect, unlimited foresight, also the assumption that there is no foresight at all has to be excluded'. ${ }^{5}$ Therefore the assumption is made that forecasts are made about (i) the current equilibrium price and (ii) the future equilibrium price ('The presence of some foresight may always be expected', Kaldor, 1934, p. 136):

(3) $p_{t}^{\text {expeq }}:=p_{t}^{e q}+\varepsilon_{2} \quad$ with $\quad \sigma_{2}^{2}:=\operatorname{VAR}\left\{\epsilon_{2}\right\}$

(4) $p_{t+d}^{\text {exp }}:=p_{t+d}^{e q}+\varepsilon_{3} \quad$ with $\quad \sigma_{3}^{2}:=\operatorname{VAR}\left\{\varepsilon_{3}\right\}$

'It is clear, however, that the forecasts $[\ldots]$ are not accurate, ...' (Coase and Fowler, 1935, p.155). Therefore the forecasts include forecast-errors, $\epsilon_{2}, \epsilon_{3}$, with variances $\sigma_{2}^{2}$ and $\sigma_{3}^{2}$.

Departing from these sources of information, the 'natural' proxies (1) and (2) and the forecasts (3) and (4), which all contain an error, it is possible to derive the optimal anticipations. Firstly, people have to estimate the current equilibrium price. This can be based on the current price,

5. Morgenstern (1935), p. 345. 'Neben der Annahme der völligen, unbeschränkten Voraussicht scheidet aber auch - [...] - die Annahme aus, es bestünde überhaupt keine Voraussicht.' 
which is in a disequilibrium situation not exactly equal to the equilibrium price, or they can use their forecast, which is not completely correct. Depending on the quality of both sources of information a certain mix:

(5) $\hat{p}_{t}^{e q}:=\lambda_{1} p_{t}+\left(1-\lambda_{1}\right) p_{t}^{\text {expeq }}$

between them is optimal (i.e. minimises the variance) when:

(6) $\lambda_{1}=\frac{\sigma_{2}^{2}}{\sigma_{\Delta}^{2}+\sigma_{2}^{2}}$

The variance of this predicted current equilibrium equals:

(7) $\hat{\sigma}_{2}=\lambda_{1} \sigma_{\Delta}^{2}$

so, if this predicted equilibrium price is used as a proxy for the future equilibrium price the error is:

(8) $\hat{\sigma}_{1}^{2}=\sigma_{1}^{2}+\lambda_{1} \sigma_{\Delta}^{2}$

A similar dilemma exists for the anticipation of the future price. People can use the (predicted) current equilibrium price, representing the current value of the subject, which will not be totally equal to the future value, or use their forecast which also contains an error. A similar optimisation of:

(9) $p_{t+d}^{\text {pred }}=\lambda_{2} \hat{p}_{t}^{e q}+\left(1-\lambda_{2}\right) p_{t+d}^{\text {exp }}$

leads to:

(10) $\lambda_{2}=\frac{\sigma_{3}^{2}}{\hat{\sigma}_{1}^{2}+\sigma_{3}^{2}}$

The use of $p_{t+d}^{\text {pred }}$ as an anticipation of future price leads to the minimal error, given the forecastqualities $\left(\sigma^{2}\right)$ :

(11) $\sigma^{2}=\lambda_{2} \hat{\sigma}_{1}^{2}=\lambda_{2}\left(\sigma_{1}^{2}+\lambda_{1} \sigma_{\Delta}^{2}\right)$

On a market with an usual linear demand and supply curve an underestimation of the price will lead to a realised price above the equilibrium and an overestimation will lead to a realised price below the equilibrium price: 
(12) $p_{t+d}^{r e a}=p_{t+d}^{e q}\left(\frac{\beta_{s}}{-\beta_{D}}\right)\left(p_{t+d}^{p r e d}-p_{t+d}^{e q}\right)$

in which $\beta_{S}$ and $\beta_{D}$ represent the coefficients of supply and demand curve, and therefore:

(13) $\sigma_{\Delta}^{2}=\left(\frac{\beta_{s}}{-\beta_{D}}\right)^{2} \sigma^{2}$

Note that by relating the aggregated market disequilibrium to the forecast errors of individuals, it is implicitly assumed that forecast errors are not dispersed. A high forecast of one person does not compensate for a low forecast of another.

Under the assumption that $\sigma_{\Delta}^{2}$ is constant through time it follows from (11) and (13) that:

(14) $\sigma_{\Delta}^{2}=\sigma_{1}^{2} \frac{\lambda_{1} \lambda_{2}\left(\frac{\beta_{s}}{-\beta_{D}}\right)^{2}}{1-\lambda_{1} \lambda_{2}\left(\frac{\beta_{s}}{-\beta_{D}}\right)^{2}}$

The system of equations (6), (10), (8) and (14) determines a unique solution for $\lambda_{1}, \lambda_{2}, \sigma_{1}^{2}$ and $\sigma_{\Delta}^{2}$, due to the monotonicy of the functions.

In this interpretation of the cobweb model, people try to anticipate the future price, but they understand they have limited capacities to do this. As their forecast-errors $\left(\sigma_{2}^{2}\right.$ and $\left.\sigma_{3}^{2}\right)$ increase they will use the current price as an indication of current and future value of the subject to a larger extent (equation (6) and (10)). But on the other hand, the use of the 'natural' expectation will increase the systematic error, what will make the current price less valuable as a proxy for the future price (equation (8) and (14)). This decrease of the 'equilibrium revealing' character of the current price will have the opposite effect: people will use the current price to a smaller extent. Somewhere in between the total use of current prices and no use of current prices there will be an equilibrium, in which a certain mix between the use of current price and the expectations about the future price minimises the expected squared error $\left(\sigma^{2}\right)$. Schultz (1930) draws this situation (see figure I): 'The real process will more likely look like the dashed lines $a b^{\prime}, b^{\prime} c^{\prime}$ etc'. ${ }^{6}$ In this equilibrium a systematic error in the behaviour will occur, but it is reasonable for people not to correct this error since this biased error in their anticipation, in the case people understand they do not forecast perfectly, will be smaller than the unbiased error in the case 'he has no doubts of their accuracy' (Hart, 1937, p. 277).

6. Schultz (1930), p. 35. 'Der wirkliche Vorgang ähnelt eher den gestrichenen Linien $a b^{\prime}$, $b^{\prime} c^{\prime}$ usw.' 


\section{IMPLICATIONS}

Figure II: The optimal trade off between a systematic (cobweb) error and a forecast error.

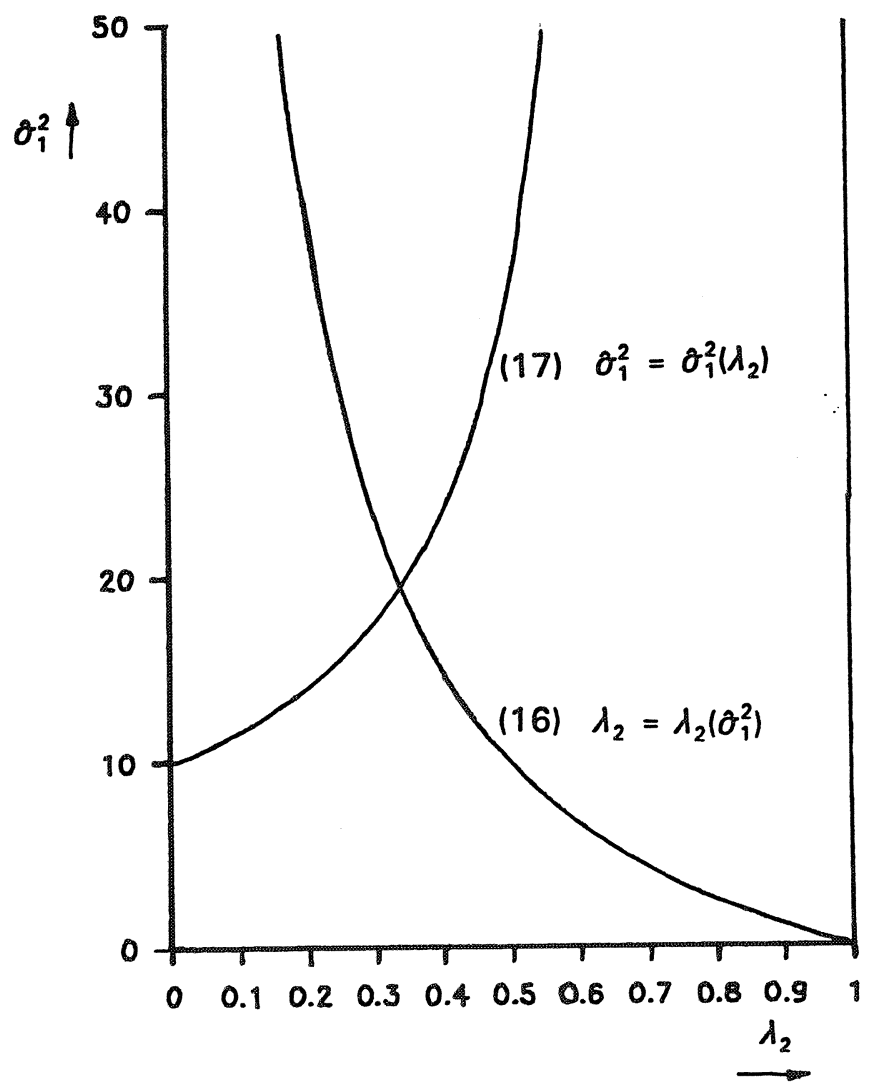

Figure II illustrates the model in a simplified case in which people are not able to correct the current price for the fact that it might not be the equilibrium price: $\sigma_{2}^{2}=\infty$ and therefore $\lambda_{1}=1$. In that case the model can be reduced to two equations:

(16) $\lambda_{2}=\lambda_{2}\left(\hat{\sigma}_{1}^{2}\right)=\frac{\sigma_{3}^{2}}{\hat{\sigma}_{1}^{2}+\sigma_{3}^{2}}$

and

(17) $\hat{\sigma}_{1}^{2}=\hat{\sigma}_{1}^{2}\left(\lambda_{2}\right)=\sigma_{1}^{2}+\sigma_{1}^{2} \frac{\lambda_{2}\left(\frac{\beta_{s}}{-\beta_{D}}\right)^{2}}{1-\lambda_{2}\left(\frac{\beta_{s}}{-\beta_{D}}\right)^{2}}$

The figure shows the equilibrium between the use of the forecast and the 'myopic' cobweb behaviour. (17) states that the quality of the current price as a proxy for the future price 
decreases as it is used to a larger extent. If $\lambda_{2}=1$ people totally rely on the current price as prediction for the future price. In the case illustrated in the figure this would lead to a diverging price, i.e. $\hat{\sigma}_{1}^{2}$ would become infinitely large. According to (16) people will make less use of the current price, as a proxy for the future price, if its forecast quality decreases ( $\hat{\sigma}_{1}^{2}$ increases). At the intersection there is an equilibrium in which the prediction error $\left(\sigma^{2}\right)$ is minimised.

Figure III shows what will happen when the ability to forecast increases (i.e. $\sigma_{3}^{2}$ decreases). (16) will shift to the right, since for a certain value of $\hat{\sigma}_{1}^{2}$ people will make more use of their (improved) forecast. Initially this leads to shift a from the use of the myopic expectation to the use of the forecast. But due to this the error of the current price as proxy of the future price $\left(\hat{\sigma}_{1}^{2}\right)$ will decrease. To reestablish the equilibrium, people will again use the current price to a greater extent (shift $b)$.

Figure III: The change in the optimal trade off caused by an increase in the ability to forecast.
Figure IV: The Change in the optimal trade off caused by a stabilisation of the market
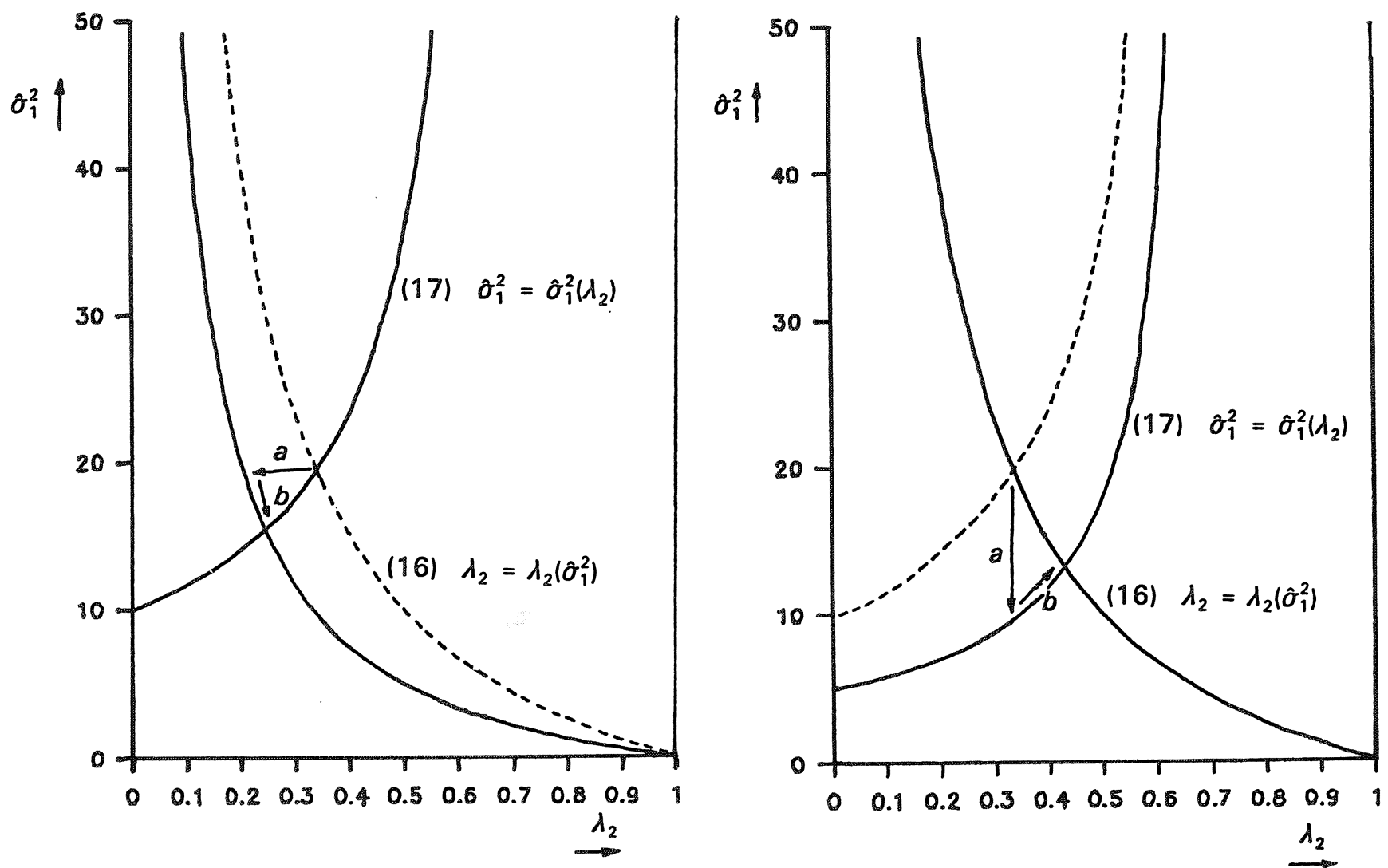
$-9-$

Figure IV shows the case in which the market is stabilised ( $\sigma_{1}^{2}$ decreases). This implies a downwards shift of (17), because the destabilising effect of the use of the current price as a proxy for the future price will decrease, given the extent to which it is used $\left(\lambda_{2}\right)$ (shift a). Again the decrease of $\sigma_{1}^{2}$ is compensated by the fact that people use the myopic forecast to a larger (axtent (shift b). In the new equilibrium the use of the current price will be larger than initially, but also the systematic error $\left(\hat{\sigma}_{1}^{2}\right)$ will decrease.

Figure V: Changes in the optimal trade off caused by increases in the ability to correct the current price for its disequilibium character.

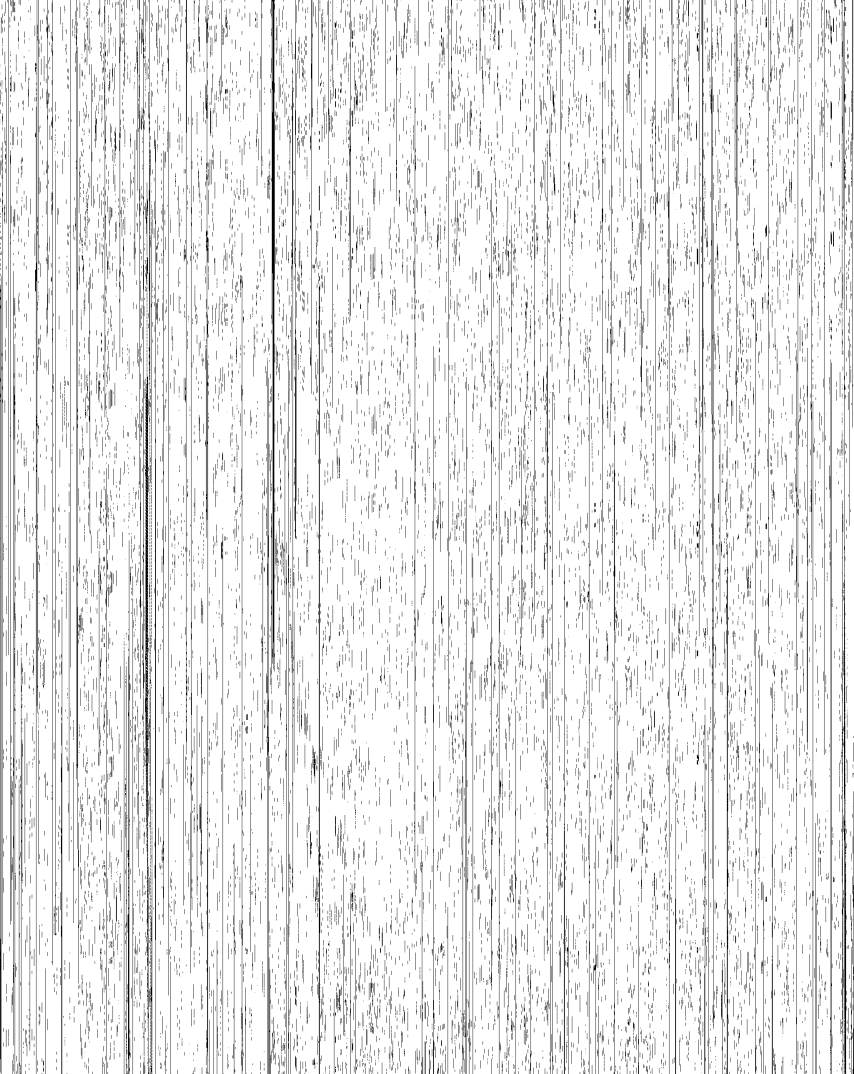

Finally, in figure $V$ the assumption that the current equilibrium is unpredictable $\left(\sigma_{2}^{2}=\infty, \lambda_{1}=1\right)$ is released. The picture allows for the fact that people are able to correct the current price for its disequilibrium character, to some extent. If people are more able to correct for disequilibrium situations (17) also depends on $\lambda_{1}$ (see equation (14)) and this function will become less steep if $\sigma_{2}^{2}$ decreases. Therefore, the market will stabilise and people will make more use of current prices as indicators of future prices. 


\section{CONCLUSIONS}

In this paper a model is introduced which gives an interpretation of the cobweb theory developed in the thirties by economists like Tinbergen and Schultz. An attempt has been made to illustrate the dilemma which characterises their expectations theory. On the one hand, inspired by Walras and Pareto, prices were seen as indicators of the value of their subject and people were assumed to use this information and to 'take prices given'. On the other hand, these equilibrium prices could (in a dynamic context) only be the result of people's economic behaviour. The model in this paper shows that it is possible to give 'myopic' expectations a rational or reasonable interpretation. The cobweb-expectations which are biased might be preferred by people since this systematic error might be smaller than the unsystematic error of the alternative, an expectation which is not biased. 


\section{REFERENCES}

Coase, R.H., R.F. Fowler (1935), 'Bacon Production and the Pig-cycle in Great Britain'. Economica 2.

Debreu, G. (1959), Theory of Value. New Haven.

Ezekiel, M. (1938), 'The Cobweb Theorem'. Quarterly Journal of Economics 52.

Haas, G.C., M. Ezekiel (1926), Factors Affecting the Price of Hogs. United States Department of Agriculture, Department Bulletin No. 1440, Washington, D.C.

Haavelmo, T. (1944), 'The Probability Approach in Econometrics'. Supplement to Econometrica 12.

Hanau, A. (1927), Die Prognose der Schweinepreise. Vierteljahrshefte zur Konjunkturforschung, Sonderheft 2, Berlin.

Hayek, F. (1945), 'The Use of Knowledge in Society'. American Economic Review 35, pp. 519-553.

Hart, A.G. (1937), 'Anticipations, Business Planning, and the Cycle'. Quarterly Journal of Economics 51.

Hicks, J.R. (1935), 'Gleichgewicht und Konjunktur'. Zeitschrift für Nationalökonomie IV. Kaldor, N. (1934), 'A Classificatory Note on the Determinateness of Equilibrium'. The Review of Economic Studies 1.

Keuzenkamp, H.A. (1989), 'The Prehistory of Rational Expectations'. Center discussion paper no. 8931, Tilburg.

Lange, O. (1935), 'Formen der Angebotsanpassung'. Zeitschrift für Nationalökonomie VI, p. 358-365.

Moore, L. (1929), Synthetic Economics. New York.

Morgenstern, O. (1934), 'Das Zeitmoment in der Wertlehre'. Zeitschrift für Nationalökonomie V.

Morgenstern, O. (1935), 'Vollkommene Voraussicht und wirtschaftliches Gleichgewicht'. Zeitschrift für Nationalökonomie VI.

Ricci, U. (1930), 'Die "synthetische Ökonomie" von Henry Ludwell Moore'. Zeitschrift für Nationalökonomie I.

Schultz, P. (1930), Der Sinn der statischtischen Nachfragekurven. Veröffentlichen der Frankfurter Gesellschaft für Konjunkturforschung, heft 10, Bonn.

Shaw, G.K. (1989), 'Expectations in Macroeconomics'. In D. Greenberg (ed.), Current Issues in Macroeconomics. Hampshire.

Tinbergen, J (1930), 'Bestimmung und Deutung von Angebotskurven. Ein Beispiel'. Zeitschrift für Nationalökonomie I. 
$-12-$

Tinbergen, J. (1932), 'Ein Problem der Dynamik'. Zeitschrift für Nationalökonomie III.

Tinbergen, J. (1933), 'The Notions of Horizon and Expectancy in Dynamic Economics'. Econometrica 2. 
CIP-GEGEVENS KONINKLIJKE BIBLIOTHEEK, DEN HAAG

\section{Borghans, Lex}

The cobweb theorem: a rational interpretation / Lex Borghans. - Maastricht : Research Centre for Education and Labour Market, Faculty of Economic Sciences, Rijksuniversiteit Limburg. (Research Memorandum / Researchcentrum voor Onderwijs en Arbeidsmarkt ; 1991 /7E).

Met lit. opg.

ISBN 90-5321-067-9 in spiraalband

Trefw.: arbeidsmarkt. 


\section{INTRODUCTION}

In 1930 Ricci, Tinbergen and Schultz published studies containing the first explicit models of a theory, which has since come to be known as the 'cobweb theorem'. This name stems from Kaldor (1934). The cobweb-theory has been the first explicit economic theory about expectations-formation. Later the construction of variants of this cobweb-theory, like extrapolative and adaptive expectations (see Shaw, 1989), leaded to the formulation of the rational expectations theory of Muth (1961). In the development of a new theory the interpretation of the predecessor very often gets adjusted to the new ideas. This also happened to the cobweb-theory, which is now typified as a naive theory of myopic agents, or as a special case of the rational expectation theory in which the stochastic process which generates future developments is, conditional on the information the agents have, a random walk.

Figure I: An illustration of the cobweb theorem by Schultz (1930), p. 34: 'Fixed demand curve and fixed supply curve with the time series that might be caused by them."

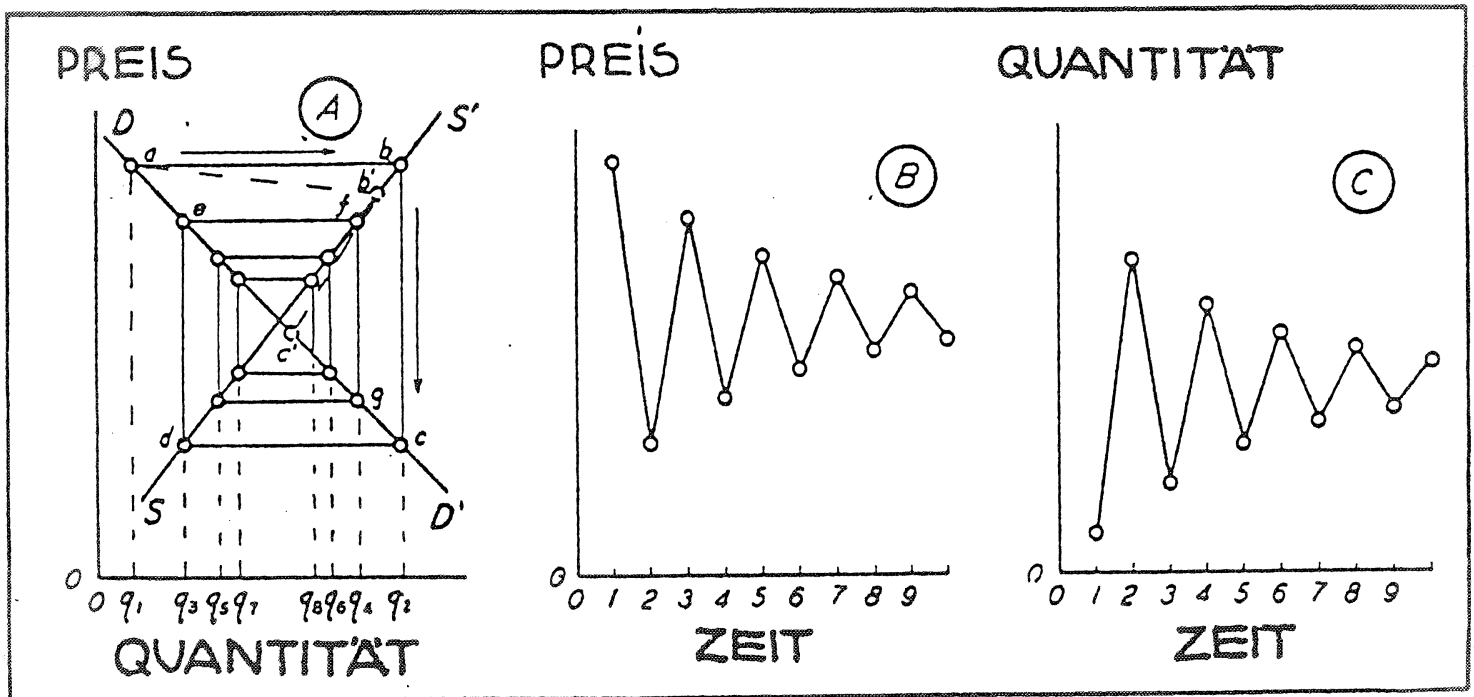

In my opinion this vision about the cobweb-theory is influenced by some economic concepts which are standard nowadays, but which did not exist in the thirties. Firstly, the present economic theory is dominated by the idea from Haavelmo (1944) that the economic development has to be viewed upon as a stochastic process. Secondly, the concept of equilibrium has changed throughout the years. Hicks (1933) defined equilibrium as 'the price which under constant conditions for demand and stock, can be preserved unlimited, in such a way that

1. 'Feste Nachfragekurve und feste Nachfragekurve [Most likely this should be 'Angebotskur$\left.v^{\prime}\right]$ mit Zeitreihen, die sie verursachen können.' 


\section{IMPLICATIONS}

Figure II: The optimal trade off between a systematic (cobweb) error and a forecast error.

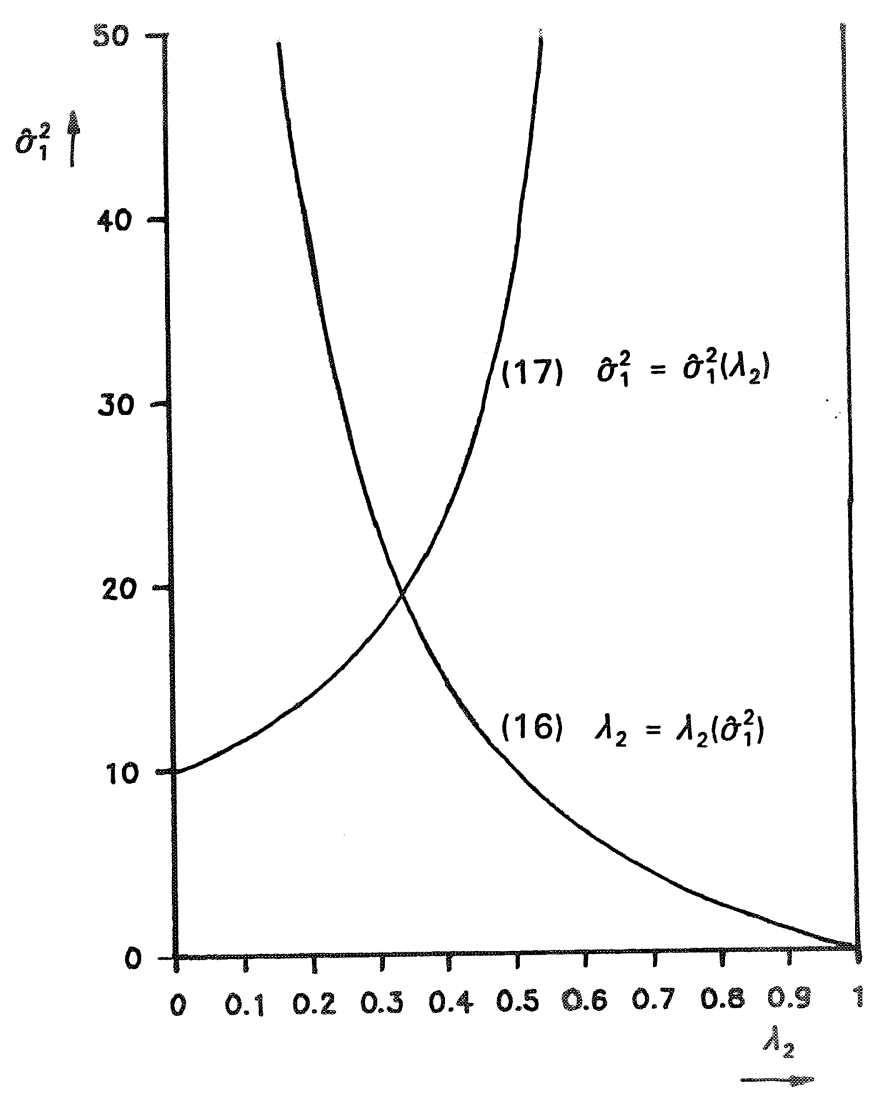

Figure II illustrates the model in a simplified case in which people are not able to correct the current price for the fact that it might not be the equilibrium price: $\sigma_{2}^{2}=\infty$ and therefore $\lambda_{1}=1$. In that case the model can be reduced to two equations:

(16) $\lambda_{2}=\lambda_{2}\left(\hat{\sigma}_{1}^{2}\right)=\frac{\sigma_{3}^{2}}{\hat{\sigma}_{1}^{2}+\sigma_{3}^{2}}$

and

(17) $\hat{\sigma}_{1}^{2}=\hat{\sigma}_{1}^{2}\left(\lambda_{2}\right)=\sigma_{1}^{2}+\sigma_{1}^{2} \frac{\lambda_{2}\left(\frac{\beta_{s}}{-\beta_{D}}\right)^{2}}{1-\lambda_{2}\left(\frac{\beta_{s}}{-\beta_{D}}\right)^{2}}$

The figure shows the equilibrium between the use of the forecast and the 'myopic' cobweb behaviour. (17) states that the quality of the current price as a proxy for the future price 
decreases as it is used to a larger extent. If $\lambda_{2}=1$ people totally rely on the current price as prediction for the future price. In the case illustrated in the figure this would lead to a diverging price, i.e. $\hat{\sigma}_{1}^{2}$ would become infinitely large. According to (16) people will make less use of the current price, as a proxy for the future price, if its forecast quality decreases ( $\hat{\sigma}_{1}^{2}$ increases). At the intersection there is an equilibrium in which the prediction error $\left(\sigma^{2}\right)$ is minimised.

Figure III shows what will happen when the ability to forecast increases (i.e. $\sigma_{3}^{2}$ decreases). (16) will shift to the right, since for a certain value of $\hat{\sigma}_{1}^{2}$ people will make more use of their (improved) forecast. Initially this leads to shift a from the use of the myopic expectation to the use of the forecast. But due to this the error of the current price as proxy of the future price $\left(\hat{\sigma}_{1}^{2}\right)$ will decrease. To reestablish the equilibrium, people will again use the current price to a greater extent (shift $b$ ).

Figure III: The change in the optimal trade off caused by an increase in the ability to forecast.
Figure IV: The Change in the optimal trade off caused by a stabilisation of the market
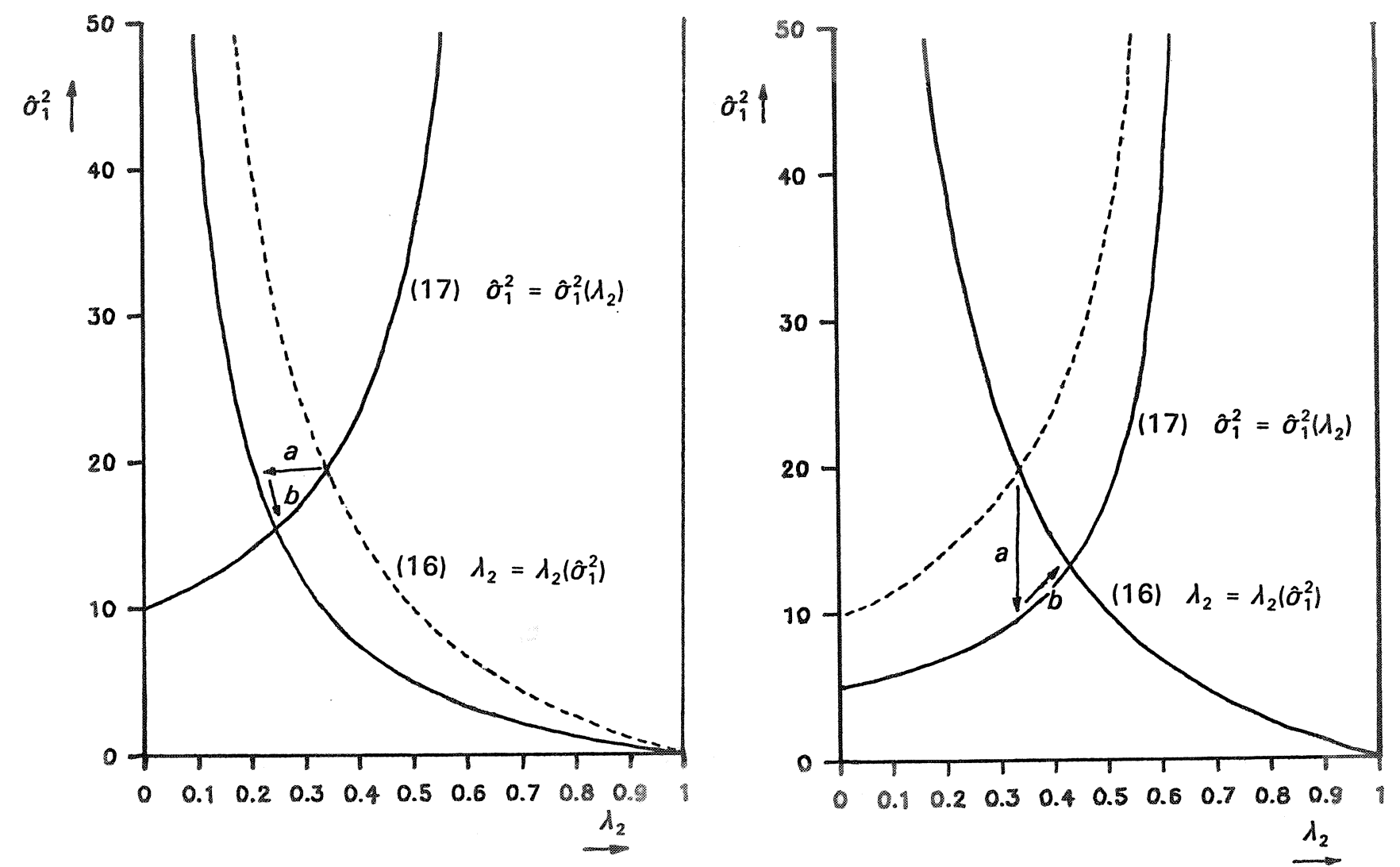
Figure IV shows the case in which the market is stabilised $\left(\sigma_{1}^{2}\right.$ decreases $)$. This implies a downwards shift of (17), because the destabilising effect of the use of the current price as a proxy for the future price will decrease, given the extent to which it is used $\left(\lambda_{2}\right)$ (shift a). Again the decrease of $\sigma_{1}^{2}$ is compensated by the fact that people use the myopic forecast to a larger extent (shift $b$ ). In the new equilibrium the use of the current price will be larger than initially, but also the systematic error $\left(\hat{\sigma}_{1}^{2}\right)$ will decrease.

Figure V: Changes in the optimal trade off caused by increases in the ability to correct the current price for its disequilibium character.

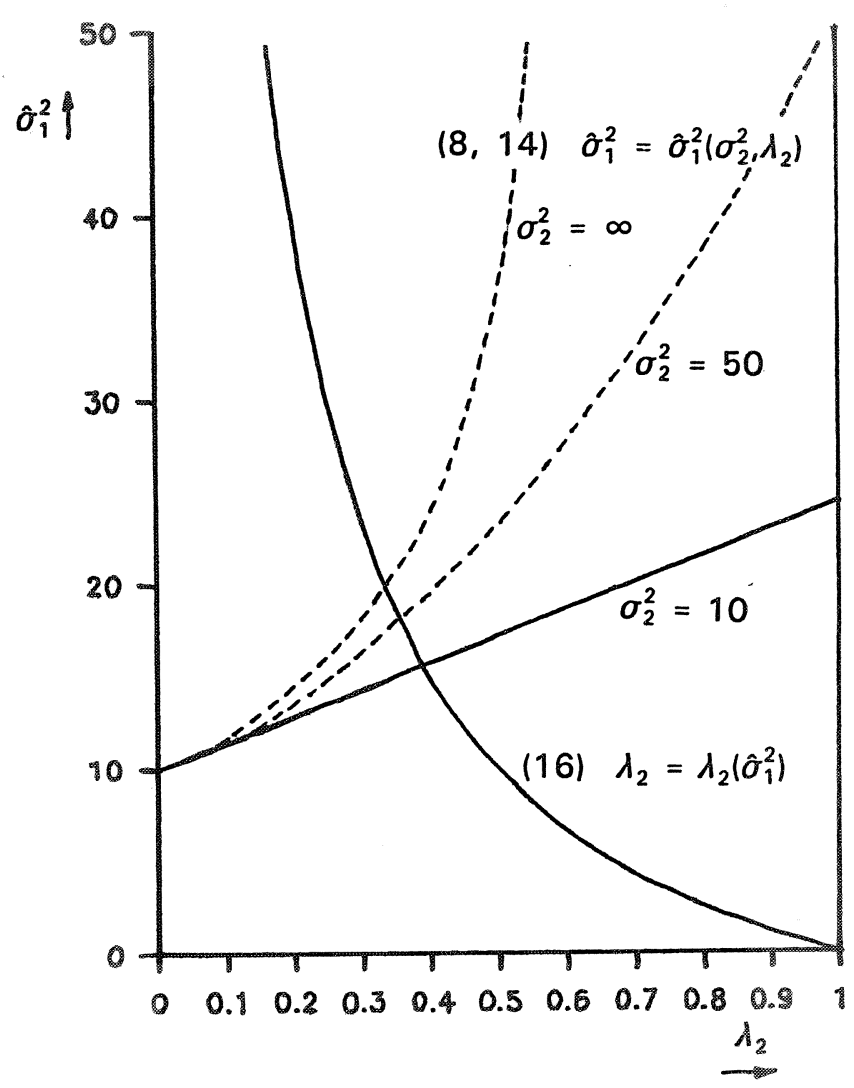

Finally, in figure $V$ the assumption that the current equilibrium is unpredictable $\left(\sigma_{2}^{2}=\infty, \lambda_{1}=1\right)$ is released. The picture allows for the fact that people are able to correct the current price for its disequilibrium character, to some extent. If people are more able to correct for disequilibrium situations (17) also depends on $\lambda_{1}$ (see equation (14)) and this function will become less steep if $\sigma_{2}^{2}$ decreases. Therefore, the market will stabilise and people will make more use of current prices as indicators of future prices. 